\title{
ReSEARChArticle
}

\section{Prevalance and perpetuation of chilli fruit rot pathogen (Colletotrichum spp.)}

Priyanka Shinde, B.G. Barhate and K. Greeshma

\begin{abstract}
SUMMARY
Chilli (Capsicum annum L.) is one of the most important spice crop grown in India. Colletotrichum spp. viz., which is the casual agent of anthracnose disease and has been reported to cause infection and also cause infection in humans. During the survey in chilli growing areas of western Maharashtra among the seven districts maximum incidence (24\%) of fruit rot was observed in Pune district. Three species of Colletotrichum, viz., Colletotrichum capsici, Colletotrichum gloeosporiodies and Colletotrichum acutatum are known to be associated with fruit rot. Perpetuation studies revealed that the conidia of three Colletotrichum spp. got perpetuated in both sterile soil and field soil but viability of conidia was maximum in sterile soil. Conidia of all three species survived upto 60 days in sterile soil but conidia completely lost viability within 60 days in field soil. The diseased fruit also showed reduction in capsaicin content by 34.7 per cent.
\end{abstract}

Key Words : Chilli fruit rot, Colletotrichum spp., Prevalence, Viability, Fruit quality

How to cite this article : Shinde, Priyanka, Barhate, B.G. and Greeshma, K. (2018). Prevalance and perpetuation of chilli fruit rot pathogen (Colletotrichum spp.). Internat. J. Plant Sci., 13 (2): 245-248, DOI: 10.15740/HAS/IJPS/13.2/245-248, Copyright@ 2018: Hind Agri-Horticultural Society.

Article chronicle : Received : 10.05.2018; Revised : 14.06.2018; Accepted : 25.06.2018

Email : bgbarhate@gmail.com

Address of the Co-authors:

Priyanka Shinde and K. Greeshma, Department of Plant Pathology and Agricultural Microbiology, Mahatma Phule Krishi Vidyapeeth, Rahuri, Ahmednagar (M.S.) India 